\title{
An Investigation of the Transportation Requirements for Fusion Power Plants
}

\author{
by \\ R. E. Rhoads \\ D. K. Davis
}

September 1976

Prepared for the Energy Research and Development Administration under Contract E(45-1)-1830 
NOTICE

This report was prepared as an account of work sponsored by the United States Government. Neither the United States nor the Energy Research and Development Administration, nor any of their employees, nor any of their contractors, subcontractors, or their employees, makes any warranty, express or implied, or assumes any legal liability or responsibility for the accuracy, completeness or usefulness of any imformation, apparatus, product or process disclosed, or represents that its use would not infringe privately owned rights.

\author{
PACIFIC NORTHWEST LABORATORY \\ operated by \\ BATTELLE \\ for the
}

ENERCY RESEARCH AND DEVELOPMENT ADMINISTRATION

Under Contract E(45-1)-1830

Printed in the United States of America

Availabie from

National Technical information Service

U.S. Department of Commerce

5285 Port Royal Road

Springfield, Virginia 22151

Price: Printed Copv \$4.50; Microfiche \$2.25

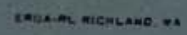




\section{6}

\section{AN INVESTIGATION OF THE \\ TRANSPORTATION REQUIREMENTS FOR \\ FUSION POWER PLANTS}

by

R.E. Rhoads

D.K. Davis

September 1976

Battel le

Pacific Northwest Laboratories

Richland, Washington 99352 
Fusion reactor technology has developed far enough to expect laboratory demonstration of practical levels of fusion employing the D-T reaction to occur in the early 1980s. Following that demonstration, and depending upon the national priorities for energy from D-T fusion, construction and operation of experimental reactors and demonstration power reactors could occur before the end of this century. Operation of the first commercial power plants could then follow, starting about 2010.

Development and adoption of a new power system eventually will require a description of the environmental effects in an environmental statement providing a comparison to the effects of competitive systems. In anticipation of that statement, an environmental analysis (BNWL-2010) has been prepared for the ERDA Division of Magnetic Fusion Energy. That analysis estimates the environmental effects of constructing and operating $D-T$ fusion reactors as an economically competitive source of electricity in the 21 st century.

The analysis has four primary purposes:

1. To describe the general nature of the environmental effects,

2. To determine current ability to estimate the effects,

3. To determine methods for reducing the effects, and

4. To determine research necessary for increasing capability to define and reduce the effects.

Timely identification of needed research and methods for reducing effects will permit the performance of that research and the revision of conceptual fusion power plant designs before preparation of the program environmental statement. This would improve the quality of the environmental statements and could reduce the estimated adverse environmental effects due to fusion power plants.

The environmental analysis (BNWL-2010) concludes that the following assumed characteristics are the best set for the first operating fusion power plants:

- The D-T fusion reaction

- Large quantities of activation products

- Kilogram quantities of tritium in the plant systems

- Massive reactor structures

- Large lithium inventories

- Large inventories of liquid metals and salts
- Standard electricity generation

- Standard radioactive waste systems

- Large magnetic fields

- A self-contained fuel cycle

- Rural siting

Using these characteristics a reference reactor was analyzed to determine the environmental effects by using available concepts of plant subsystems designs that control interactions with the environment or by assumption that best current technology would be used in subsystems design. Because this analysis does not take into account advances in both fusion and waste control technology during the next thirty years, the estimated effects probably are significantiy higher than the actual effects will be for the first fusion power plants. The estimated environmental effects should be interpreted only as being the probable upper limit for the actual effects. 
Preparation of the fusion power plant environmental analysis required development and use of specially developed data and analysis methods not used in the preparation of current environmental statements for fossil and fission power plants. These data and analysis requirements are documented in a series of reference topical reports to make this information publicly available and to assure understanding of the basis for the conclusions made in the environmental analysis. These reference topical reports summarize the state-of-the-art as applicable to preparation of environmental statements for fusion power plants. They present the data and analytical techniques used in the environmental analysis to estimate the interactions with the environment and the resultant environmental effects. This information then was analyzed for adequacy and the need was determined for additional research to assure satisfactory ability to prepare environmental statements for the fusion development program and experimental facilities in the early 1980s. Estimated environmental effects are presented in these reference documents only as necessary to illustrate use of the data and analytical techniques.

This report is one of those reference documents for the environmental analysis. The other documents in this series contain more details of the power plant concepts and the probable environmental effects of fusion power plants with the assumed characteristics listed above. These documents are available through the National Technical Information Service:

An Environmental Analysis of Fusion Power to Determine Related R\&D Needs, BNWL-2010

Review of Fusion Research Program: Historical Sumary and Program Projections, BNWL-2011

Fuel Procurement for First Generation Fusion Power Plants. BNwL-2012

Current Fusion Power Plant Design Concepts, BNWL-2013

Reference Commerical Fusion Power Plants, BNWL-2014

Siting Commercial Fusion Power Plants, BNWL-2015

Materials Availability for Fusion Power Plant Construction, BNWL-2016

Projected Thermodynamic Efficiencies of Fusion Power Plants, BNWL-2017

Tritium Source Terms for Fusion Power Plants, BNWL-2018

Management of Nontritium Radioactive Wastes from Fusion Power Plants, BNWL-2019

Methodology for Estimating Radiation Doses Due to Tritium and Radiocarbon Releases, BNWL-2020

Magnetic Field Considerations in Fusion Power Plant Environs, BNWL-202l

Biological Effects of Tritium Releases from Fusion Power Plants, BNWL-2022

Biological Effects of Activation Products and Other Chemicals Released from Fusion Power Plants, BNWL-2023

Safety Review of Conceptual Fusion Power Plants, BNWL-2024

An Investigation of the Transportation Requirements of Fusion Power Plants, BNWL-2025

Considerations of the Social Impact of Fusion Power, BNWL-2026

Environmental Impacts of Nonfusion Power Systems, BNWL-2027

Environmental Cost/Benefit Analysis for Fusion Power Plants, BNWL-2028

Biomagnetic Effects: A Consideration in Fusion Reactor Development, BNWL-1973

An Analysis of Tritium Releases to the Atmosphere by a CTR, BNWL-1938 


\section{CONTENTS}

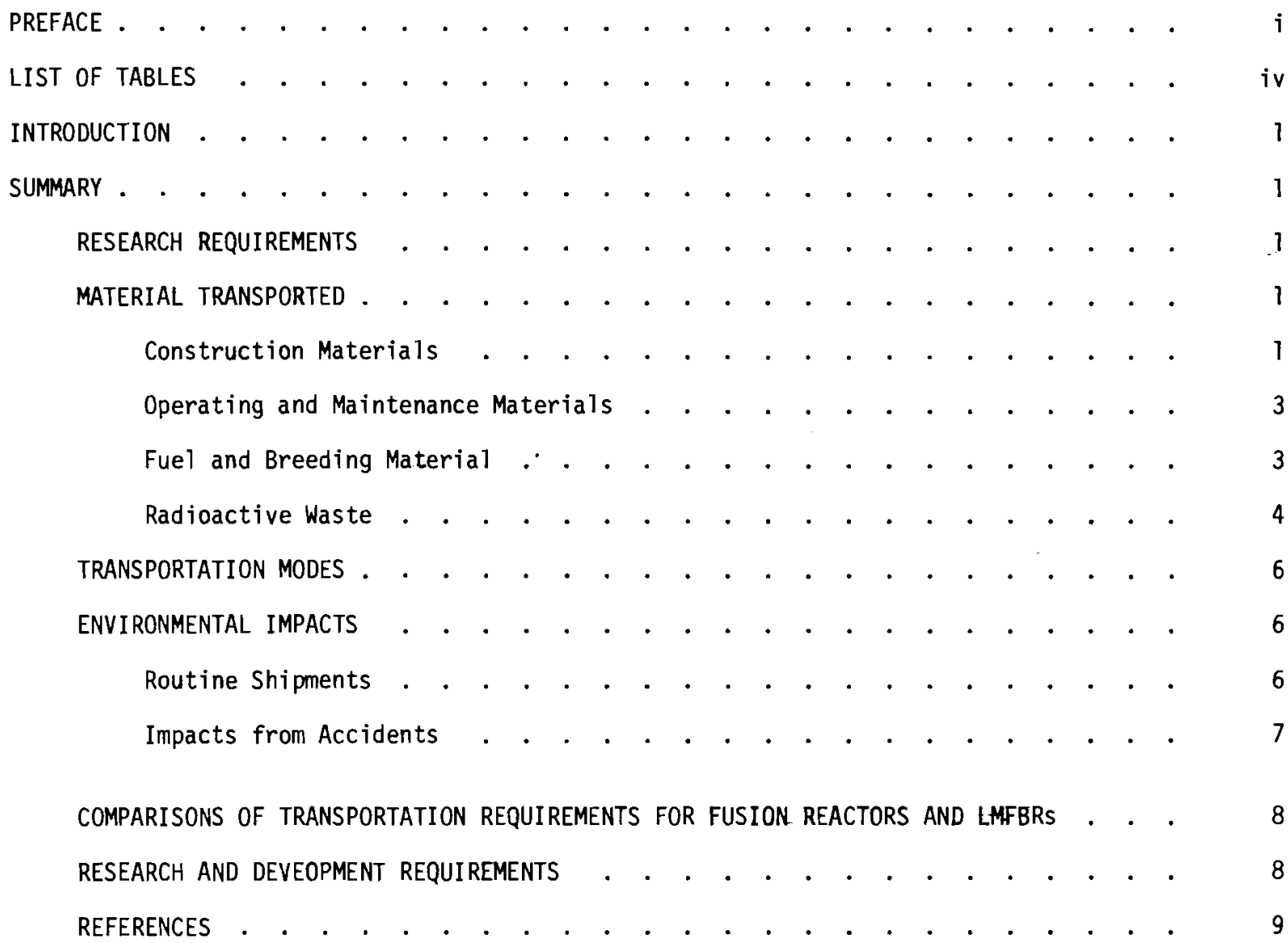




\section{LIST OF TABLES}

1 Normalized Fusion Power Plant Construction Material Requirements . • • • • . . 2

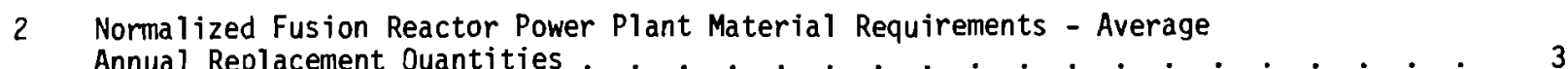

3 Blanket Radioactivity and Heat Generation Rates at Shutdown . . . . . . . . . 5

4 Comparison of Annual Transportation Requirements for Reference . . . . . . . . . $\quad 8$ 
This report presents a general investigation of the transportation requirements associated with the construction and operation of conceptual fusion reactors. Projections of amounts of construction and operating materials requiring transportation are presented for several proposed designs. The material to be shipped is described along with the shipping containers that might be used, the transport modes and the expected impact of transporting these materials. Transportation of both radioactive and nonradioactive materials will be required. Most of these materials are routinely shipped by the transportation industry. Transportation requirements of a representative fusion reactor are also compared with Liquid Metal Fast Breeder Reactor (LMFBR) requirements.

$\underline{\text { SUMMARY }}$

The environmental impact of the transportation of materials to and from fusion power plants is not expected to be significant. The amount of material to be shipped represents a very small fraction of the total amount of goods and materials shipped annually in the U.S. Some developmental work may have to be undertaken to design and produce radioactive material packaging better suited to the requirements of fusion reactors than is currently available. Development of new packaging is expected to be primarily an application of existing technology to meet the special needs when those needs are established. Although some of the materials shipped to and from fusion power plants are hazardous, the probability of accidental release to the environment is believed to be low. Methods are available for estimating the environmental effects of transporting materials for fusion reactors. Although these environmental effects are believed to be small, they could be reduced further by design alternatives in the fusion devices and in hazardous materials transport systems.

RESEARCH REQUIREMENTS

The risk associated with transportation has not been accurately assessed for all hazardous materials, some of which may have to be transported for fusion reactors. The risks for transporting these materials should be determined when the final designs for specific experimental and commercial fusion reactors are known. In the near future, because these materials are expected to be used in most experimental devices and probably in the first generation fusion reactors, the transportation risks should be determined for deuterium, tritium, and lithium.

\section{MATERIAL TRANSPORTED}

\section{Construction Materials}

Current conceptual designs indicate that fusion power plants may be as large as five thousand megawatts thermal. Large quantities of construction materials will be required to build these plants, as shown in Table 1. The UWMAK-I design will be used to illustrate construction material transportation requirements, since it is the largest device for which extensive information is available.

For a nominal 1000 megawatt (electric) power plant, about 600,000 metric tons of construction materials will be required. About 460,000 metric tons of this material is concrete which will be moved primarily by local transportation. The remaining material is assumed to be delivered to 
TABLE 1 Normalized Fusion Power Plant Construction Material Requirements* (Metric Ton/MWe)

\begin{tabular}{|c|c|c|c|c|c|c|}
\hline Element & $\begin{array}{l}\text { UWMAK I } \\
\text { (Total) }\end{array}$ & $\begin{array}{c}\text { PPPL } \\
\text { (Total) }\end{array}$ & $\begin{array}{l}\text { etric Ton/MWe } \\
\text { Theta Pinch } \\
\text { (Total) }\end{array}$ & $\begin{array}{l}\text { ORNL } \\
\text { (Nuclear Is1 and) }\end{array}$ & $\begin{array}{c}\text { Mirror } \\
\text { (Reactor and } \\
\text { Converter) }\end{array}$ & $\begin{array}{c}\text { BNL } \\
\text { (Blanket } \\
\text { and Shield) } \\
\end{array}$ \\
\hline Al & 0.54 & 0.008 & - & - & - & 1.55 \\
\hline B & 1.07 & - & - & - & - & 3.61 \\
\hline $\mathrm{Be}$ & - & 0.43 & 0.012 & - & - & 0.12 \\
\hline c & 0.30 & - & - & 2.12 & 1.40 & 1.96 \\
\hline $\mathrm{Cr}$ & 7.92 & 2.82 & - & 0.07 & 44.00 & - \\
\hline $\mathrm{Cu}$ & 7.27 & 1.61 & 2.27 & 0.87 & 52.00 & - \\
\hline $\mathrm{F}$ & - & 2.6 & - & - & - & - \\
\hline $\mathrm{Fe}$ & 77.80 & 5.87 & - & 12.40 & 146.00 & - \\
\hline $\mathrm{He}$ & 0.09 & 0.06 & 0.29 & 0.002 & - & - \\
\hline $\mathrm{Hg}$ & 0.002 & - & - & - & - & - \\
\hline K & - & - & - & 0.02 & - & - \\
\hline Li & 1.15 & 0.29 & 0.39 & 0.89 & 0.48 & 0.04 \\
\hline Mn & 0.82 & 0.08 & - & - & 4.40 & - \\
\hline Mo & 0.41 & 0.14 & - & - & - & - \\
\hline $\mathrm{Na}$ & 12.10 & - & - & - & - & - \\
\hline $\mathrm{Nb}$ & 0.09 & 0.05 & 0.88 & 1.93 & - & - \\
\hline $\mathrm{Ni}$ & 5.90 & 0.81 & - & 0.05 & 27.00 & - \\
\hline $\mathrm{Pb}$ & 13.90 & - & - & 10.30 & 7.50 & - \\
\hline $\mathrm{Sn}$ & - & 0.02 & - & - & - & - \\
\hline $\mathrm{Ti}$ & 0.05 & 0.008 & - & 1.24 & - & - \\
\hline Y & 0.003 & - & - & - & - & - \\
\hline $2 r$ & 0.07 & 0.0005 & - & 0.002 & - & - \\
\hline Concrete & 461.00 & 15.8 & - & 38.60 & $\underline{225.00}$ & - \\
\hline Totals & 590.49 & 28.60 & 3.84 & 68.49 & 507.80 & 7.28 \\
\hline
\end{tabular}

* BNWL-2013

the plant site during a five-year construction period. This results in long distance transportasion requirements of about 28,000 metric tons per year.

The majority of the construction materials are routinely shipped throughout the U.S. and have no special transportation requirements. Highly chemically reactive materials such as fluorine, potassium, sodium and lithium require special handling during transportation. Transportation of these materials is not a unique requirement of fusion reactors, however. All have been regularly shipped in the United States for many years.

Fluorine is normally shipped as hydrogen fluoride (HF) gas in pressurized containers. It is classified as a corrosive substance and its transportation is regulated by the Department of Transportation (DOT). Pressurized containers in a variety of sizes are authorized for HF gas. The most economical method to ship the large quantities required for a fusion reactor would be by railroad tank car. The tank cars specified for HF are circular cross section tanks with steel walls a minimum of 43 millimeters thick. The tanks are loaded and unloaded through values in a manway cover on top of the tank. No other penetrations are permitted. All valves are constructed of materials that resist the corrosive action of $\mathrm{HF}$. 
The alkali metals are classified as flammable solids and their transport is also regulated by DOT. Sodium metal can be transported as a solid in metal drums, steel cylinders with overpacks, tank trucks or railroad tank cars. Railroad tank cars would again be preferred for economic reasons. The tank cars authorized are similar to those specified for HF. The sodium is loaded as a liquid and allowed to solidify before it is shipped. The tank car has external heating coils for off-loading. Lithium may be shipped as a solid in metal drums, in steel cylinders with overpacks or covered with a neutral oil in metal drums. Potassium may be shipped in steel cylinders in overpacks or covered with oil in a metal drum.

Operating and Maintenance Materials

Materials will be shipped to replace the equipment and materials expended during operation of a fusion reactor. The bulk of these shipments result from the requirement to periodically replace sections of the inner blanket. Annual material requirements for inner blanket replacement are indicated in Table 2 for the various conceptual designs. Again, using data for UWMAK I, a nominal 1000 MWe plant would require transportation of about 400 metric tons of inner blanket material per year. Other maintenance materials (pumps, motors, and spare parts) and operating materials (water treatment chemicals) also will be required. All of the maintenance and operating materials require only routine shipments with no special handling.

TABLE 2 Normalized Fusion Reactor Power Plant Material Requirements Average Annual Replacement Quantities*

(Metric Ton/1000 MWe)

\begin{tabular}{|c|c|c|c|c|c|c|}
\hline Element & UWMAK-I & $\underline{P P L}$ & ORNL & Theta Pinch & Mirror & BNL Blanket \\
\hline Al & 4.9 & & & & & 157.0 \\
\hline $\mathrm{Be}$ & & & & 2.4 & & 0.6 \\
\hline C & & & 212.0 & & 66.0 & 108.0 \\
\hline $\mathrm{Cr}$ & 8.7 & 19 & & & 37.0 & \\
\hline $\mathrm{Cu}$ & 4.9 & & & 0.5 & & \\
\hline $\mathrm{Fe}$ & 302.0 & 42 & & & 118.0 & \\
\hline $\mathrm{He}$ & & & & 0.2 & & \\
\hline$M n$ & 9.5 & & & & & \\
\hline Mo & 9.5 & & & & 3.7 & \\
\hline $\mathrm{Nb}$ & & & 27.0 & 20.0 & & \\
\hline $\mathrm{Ni}$ & 68.0 & 46 & & & 22.0 & \\
\hline $\mathrm{Zr}$ & & & 0.3 & & & \\
\hline Tota1s & 407.5 & 107 & 239.3 & 23.1 & 246.7 & 265.6 \\
\hline
\end{tabular}

* BNWL-2013.

Fuel and Breeding Material

Routine shipments of deuterium fuel and possibly lithium breeding material will be required for operation of a fusion reactor. Transportation of initial supplies of tritium and deuterium fuels is also required. Initial tritium requirements are expected to be about $10 \mathrm{kilo-}$ grams (Senhert, 1974). Annual deuterium requirements are expected to be about $90 \mathrm{~kg}$. About 4 metric tons of 1 ithium may be required each year for some designs. Transportation of lithium was discussed previously. Shipping methods for tritium and deuterium are presented below. 
Deuterium is presently shipped either as a gas or as heavy water $\left(D_{2} O\right)$. Gas shipments are made in specially designed pressure bottles with a $1 \mathrm{~kg}$ deuterium capacity. Metal drums are used for heavy water shipments.

Tritium is expected to be shipped fixed in a solid such as $\mathrm{Ca}(\mathrm{OT})_{2}$. The specific activity of $\mathrm{Ca}(\mathrm{OT})_{2}$ ready for shipment is estimated as $5.3 \times 10^{5}$ curie per cubic meter with a heat generation rate of 2.1 watts per cubic meter (WASH-1535, p. 4.5-29). Quantities up to 1000 curies of tritium [about 19 liters of $\mathrm{Ca}(\mathrm{OT})_{2}$ ] may be shipped in Type A containers ( $10 \mathrm{CFR} \mathrm{n}$ ). Larger amounts require Type $B$ packaging such as the DOT Specification $6 M$ container shown in Figure 1 . Several other suitable containers are presently available (WASH-1279).

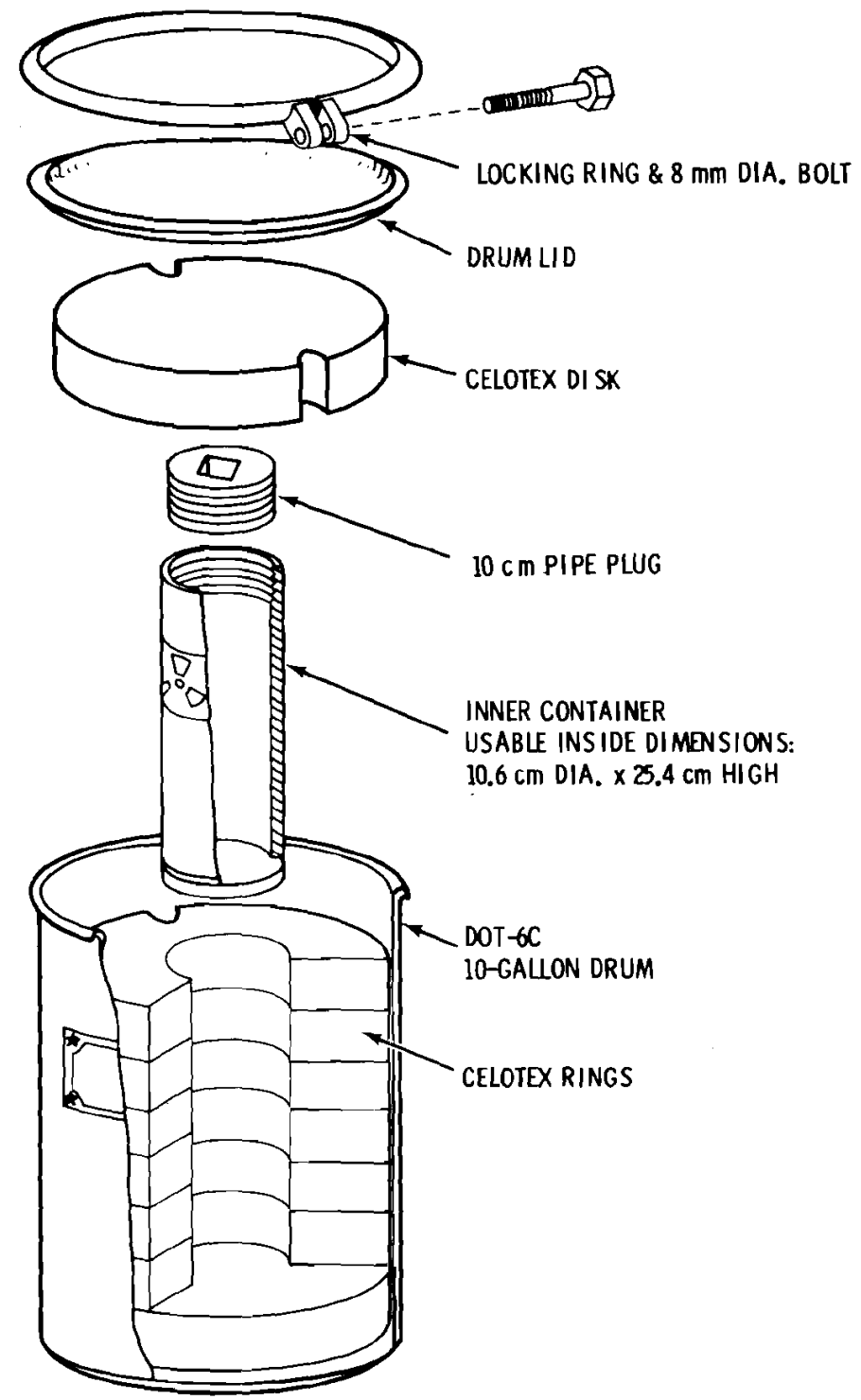

FIGURE 1 DOT Specification 6M Radioactive Material Shipping Container (WASH-1279)

\section{Radioactive Waste}

Although onsite burial of radioactive waste generated at a fusion reactor is a possibility, it is assumed here that all radioactive waste will be transported to an offsite burial ground. The majority of the radioactivity in the waste produced probably will result from the periodic remcval of portions of the inner blanket. Although about 400 metric tons will be replaced 
annually, the radioactivity and heat generation of the blanket material removed will depend on the structural material used, the neutronic characteristics of the particular device, and the cooling period before shipment.

Table 3 presents blanket radioactivity and heat generation information for the various concep tual designs.

TABLE 3 Blanket Radioactivity and Heat

Generation Rates at Shutdown

\begin{tabular}{|c|c|c|c|}
\hline Device & $\begin{array}{c}\text { Structural } \\
\text { Material } \\
\end{array}$ & $\begin{array}{l}\text { Radioactivity } \\
\text { (curies/metric } \\
\text { ton) }\end{array}$ & $\begin{array}{c}\text { Heat Generation } \\
\text { (watts/metric } \\
\text { ton) }\end{array}$ \\
\hline PPPL & PE-16 & $9 \times 10^{6}$ & $3.1 \times 10^{4}$ \\
\hline UWMAK I & SS & $8 \times 10^{6}$ & $4 \times 10^{4}$ \\
\hline Theta Pinch & Nb & $1.5 \times 10^{7}$ & $5 \times 10^{4}$ \\
\hline ORNL & $\mathrm{Nb}$ & $5 \times 10^{6}$ & $1.7 \times 10^{4}$ \\
\hline
\end{tabular}

If the blanket material will be allowed to decay for one year before it is shipped offsite, nuclides with short half-lives will be no problem. The activity of the niobium alloy blankets decreases by a factor of 100 after a one year decay period. The PE-16 (43 percent Ni, 39 percent $\mathrm{Fe}, 18$ percent $\mathrm{Cr}$ ) activity decreases to $1.1 \times 10^{6}$ curie per megaton with a heat generation rate of $1.3 \times 10^{3}$ watts per megaton (MATT-1050) after one year. Because of its longer lived activity, PE-16 will be used as the reference blanket material for transportation.

Most conceptual designs call for removal of an entire section of blanket at one time. Because of the radiation levels involved, remote handling techniques will be required to prepare this material for shipping. The blanket section is expected to be disassembled or segmented before being placed in a shielded shipping container. There are strong economic incentives to ship the blanket material in large pieces to minimize the costly remote segmentation operations. Containers are not available for economically shipping the large pieces of blanket material. However, there are no technical obstacles to the construction of an appropriate container, once specifications for the contents are set. A container must have sufficient shielding to conform with the sole use vehicle radiation limits of 49 CFR $170-179$ and 10 CFR 71 and provide adequate heat removal capacity for the amount of material to be shipped. The container would have to meet all requirements for Type $B$ non-fissile packaging so that it would maintain its integrity under the severe accident test conditions set forth in Appendix B of 10 CFR 71 .

Four hundred metric tons of the reference PE-16 blanket material would contain about $4.4 \times 10^{8}$ curies and have a heat generation rate of $5.2 \times 10^{5}$ watts. Shipment of this material poses no special technical problems. The activity and heat generation rates for spent fuel from light water fission reactors are the same order of magnitude although the radioactive material is in a more compact form. Spent fuel has been successfully transported for many years. The number of shipments of blanket material required each year will depend on the size of the shipping container that is eventually selected.

Another source of radioactive waste to be transported from fusion reactors is corrosion products collected from liquid metal coolants. Portions of the radioactive coolant tubes will be eroded by the corrosive action of the liquid metal coolants and by neutron sputtering. Current conceptual designs typically specify removal of these materials from the coolant by a purification 
process using zirconium traps. The metallic oxides and fluorides removed from the traps will be treated as solid waste. They will probably be bound in a matrix such as concrete, ureaformaldehyde, or bitumen and shipped offsite to a commercial burial ground.

Corrosion products from the reference PE-16 structures have been estimated (BNWL-2019) at 12 metric tons chromium, 0.3 metric tons iron and 0.3 metric tons nickel per year. This waste would be mixed with 17.4 metric tons of coolant and have an estimated volume of about 30 cubic meters. The radioactivity of the waste after a one-year decay period is estimated to be $1.1 \times 10^{6}$ curies with a heat generation rate of $1.4 \times 10^{3}$ watts. This material will be transported in a Type $B$ shipping container with adequate heat removal properties and shielding characteristics that conform to Federal requirements. It is assumed that, for convenience, a special container will be constructed to meet the requirements for shipment of corrosion products from fusion reactors. There are no technical obstacles to the construction of such a container. Assuming that the container has a volume of 210 liters, and the corrosion products are mixed with an equal volume of matrix material, about 280 shipments would be required annually.

Small amounts of other radioactive wastes will also be shipped from fusion reactors. These include activated hardware and gases from neutral beam accelerators, tritium contaminated amalgam from diffusion pump mercury, tritium contaminated vacuum pump oil, spent yttrium foil from tritium getter systems and routine waste such as gloves, swabs and protective clothing. All of this material will be contaminated to relatively low levels and presents no special shipping problems. Much of it will meet the requirements of Low Specific Activity (LSA) material, requiring only strong, tight industrial packaging when shipped in sole use vehicles. Two hundred and ten liter drums have been widely used for transporting LSA and Type A quantities of low level waste.

\section{TRANSPORTATION MODES}

Material will be transported to and from fusion reactors mainly by truck and rail. The size of the $i$ tem shipped and economic considerations will determine the shipping mode used for a particular material. Truck shipments are generally limited to a net weight of about 22 metric tons without costly overweight permits. Special rail cars can carry well over 90 metric tons. Rail shipments are generally less costly, but remain in transit longer. Accident rates are lower for rail shipments $(0.88 / \mathrm{million} \mathrm{km})$ than for truck $(1.5 / \mathrm{million} \mathrm{km})$ (Clark et al) but both are sufficiently low that this will have little bearing on the choice of transportation mode for a particular shipment.

Under special circumstances, barge transportation may be used. This requires port facilities at origin and destination and navigable waterways. Barge shipments may be the only feasible method for transporting very large items. Large sections of removed blanket material could be transported in this manner.

\section{ENVIRONMENTAL IMPACTS}

\section{Routine Shipments}

Negligible environmental impact is expected from the routine shipment of nonradioactive materials to and from a fusion reactor. The largest amount of material will be transported during 
the construction phase $(28,000$ metric tons per year $)$. This is a very small fraction of the total amount of material shipped annually in the United States. Annual shipments in 1971 of steel products, ferrous castings, nonferrous castings and cement amounted to $1.78 \times 10^{8}$ metric tons (U.S. Bureau of Census, 1973). National transportation requirements can be expected to increase substantially from this value by the time fusion reactor construction begins.

Routine shipments of radioactive materials are also expected to produce negligible environmental impacts. The radiation doses permitted from the packages are set at conservatively safe levels by Department of Transportation and Nuclear Regulatory Commission regulations. The amount of radioactive material shipped annually is again a very small fraction of the total amount of material transported in the U.S. Radioactive materials do require special handling but the extra manpower requirements to handle radioactive shipments from fusion reactors is insignificant. Impacts from Accidents

Some transportation accidents have the potential to cause significant environmental impacts. These include accidents involving shipments of radioactive materials, alkali metals and hydrogen fluoride. Transportation accidents involving other materials shipped to or from fusion reactors would be 1 imited to physical damage in the vicinity of the accident, and pose no unusual problems from an environmental standpoint.

Alkali metals react vigorously with water at all temperatures and with air and concrete at elevated temperatures. Since these materials are expected to be shipped as solids, usually only the reactions with water are important in transportation accidents. The large amounts of energy that could be released in alkali-metal reactions with water have the potential to produce significant damage. The combustion products released can also be harmful if inhaled. (A discussion of alkali metal reactions and reaction products is contained in BNWL-2024.) Because of their hazardous nature, alkali metals must be transported in DOT specification shipping containers. These containers are designed to resist damage and loss of their contents during normal transport and transportation accidents. The probability of the release of alkali metals to the environment in a transportation accident is kept very low.

Hydrogen fluoride gas is very toxic to man, animals and plants. It produces both acute and chronic health effects. It dilutes rapidly in the environment, however, so that effects of its release in a transportation accident are localized. Hydrogen fluoride is shipped in containers designed to withstand most accident conditions so that the probability of release of HF in an accident is low. Hydrogen fluoride has been safely shipped in the U.S. for many years.

Shipping containers for radioactive materials are designed to remain intact during severe transportation accident conditions. Containers for hazardous amounts of radioactive material must be tested under the accident conditions specified in Appendix B of 10 CFR 71 before they are certified for use by the Nuclear Regulatory Commission (NRC). The probability of release of radioactive materials in a transportation accident is low and most of the radioactive material shipped from fusion reactors is expected to be in a relatively inert chemical form. For example, the radioactivity in the replaced blanket sections is bound up in structural material and is not readily dispersible, even if the container were breached in an accident. 
Table 4 presents a comparison of transportation requirements for a nominal 1000 MWe fusion reactor and an LMFBR. Although fusion reactors may require the transportation of over twice as much construction materials, the radioactive material transportation requirements are much lower. This is primarily due to the wastes generated at LMFBR fuel cycle facilities. Transportation of spent fuel and wastes from reprocessing and fuel fabrication plants is a major consideration for LMFBRs. Similar facilities are not required for operation of a fusion reactor, since fuel preparation and processing are inherent parts of the reactor operation and generate very small amounts of waste.

TABLE 4 Comparison of Annual Transportation Requirements for Reference 1000 MWe Plants

\begin{tabular}{lll} 
& LMFBR $^{*}$ & Fusion Reactor \\
\cline { 2 - 3 } Construction Material & 216,000 metric tons & 590,000 metric tons \\
Replacement Material & -- & 400 metric tons \\
Radioactive Waste from Reactor & 56 cubic meters & 370 cubic meters \\
Radioactive Waste from Fuel & 736 cubic meters & -- \\
Fabrication Plant & 170 cubic meters & -- \\
Radioactive Waste from & 17 metric tons & 4 metric tons \\
Reprocessing Plant & 0.35 cubic meters & 0.45 cubic meters \\
Fuel & 17 metric tons & -- \\
Tritium Ca $\left(0^{3} \mathrm{H}\right)_{2}$ & 35 metric tons & --
\end{tabular}

* From WASH-1535

RESEARCH AND DEVELOPMENT REQUIREMENTS

Al though the radioactive materials expected to be transported to and from fusion reactors could be shipped in existing packaging, economic and transportation logistic consideration will make it desirable to develop packaging and transportation systems specifically designed for the materials to be shipped. The design and manufacture of new radioactive material packaging is not expected to require the development of new technologies. The engineering principals for safe, economical and convenient packaging design and construction are well known and these principals have been applied to produce packaging used extensively by current nuclear facilities. For the most part, the development of new packaging will involve the adaptation of this existing technology to meet the transportation needs of fusion power plants.

Although it is believed that the risk from accidental releases of hazardous materials transported to and from fusion reactors will be acceptably small, this risk has not been analyzed in detail for some of the hazardous substances associated with fusion reactors. Those risks should be determined for the specific materials when the final designs of the experimental and commercial power plants are known. The specific materials expected to be used in early experimental devices and for which the risks should be determined in the near future are deuterium, tritium, and lithium. 


\section{REFERENCES}

R. K. Clarke, J. T. Foley, W. F. Hartman and D. W. Larson, Severities of Transportation Accidents, Vol. IV, SLA-74-0001, Sandia Laboratories, Albuquerque, New Mexico. (To be published)

U.S. Bureau of the Census, Statistical Abstract of the United States: 1973, (94th Edition), Washington, D.C., 1973.

MATT-1050, R. G. Mills, A Fusion Power Plant, Princeton Plasma Physics Laboratory, 1974.

M. Sehnert, on the Determination of Tritium Inventories in CTR Power Plants, Masters Thesis, University of California at Los Angeles, 1974.

WASH-1279, Division of Waste Management and Transportation, Directory of Packaging for Transportation of Radioactive Materials, United States Atomic Energy Commission, Washington, D.C., 1973.

WASH-1535, Proposed Final Environmental Statement, Liquid Metal Fast Breeder Reactor Program, U.S. Atomic Energy Commission, 1974.

B. F. Gore, Current Fusion Power Plant Design Concepts, BNWL-2013, Battelle, Pacific Northwest Laboratories, Richland, WA, 1976.

J. D. Kaser, Management of Nontritium Radioactive Wastes from Fusion Power Plants, BNWL-2019, Battelle, Pacific Northwest Laboratories, Richland, WA, 1976.

R. G. Clark, Safety of Fusion Power Plant Concepts, BNWL-2024, Battelle, Pacific Northwest Laboratories, Richland, WA, 1976. 


\section{OFFSITE}

A. A. Churm

ERDA Chicago Patent

Group

9800 S. Cass Avenue

Argonne, IL 60439

J. W. Beal

ERDA Div. of Magnetic

Fusion Energy

Washington, DC 20545

S. 0. Dean

ERDA Div. of Magnetic Fusion Energy

Washington, DC 20545

E. E. Kintner

ERDA Div. of Magnetic

Fusion Energy

Washington, DC 20545

J. M. Williams

ERDA Div. of Magnetic

Fusion Energy

Washington, DC 20545

J. N. Grace

ERDA Div. of Magnetic

Fusion Energy

Washington, DC 20545

J. Baublitz

ERDA Div. of Magnetic

Fusion Energy

Washington, DC 20545

3 F. E. Coffman

ERDA Div. of Magnetic Fusion Energy

Washington, DC 20545

J. F. Decker

ERDA Div. of Magnetic

Fusion Energy

Washington, DC 20545

3 K. M. Zwilsky

ERDA Div. of Magnetic

Fusion Energy

Washington, DC 20545

Dr. Philip M. Stone

ERDA Applied Plasma Physics Program

Washington, DC 20545

G. W. Kuswa

ERDA Div. of Laser Fusion

Washington, DC 20545

\section{OFFSITE}

$R$. Blaunstein

ERDA Div. of Biomedical

and Environmental Research

Washington, DC 20545

H. M. Busey

ERDA Div. of Military

Application

Washington, DC 20545

M. A. Bell

ERDA Div. of Safety

Standards and Compliance

Washington, OC 20545

27 ERDA Technical Information Center

M. S. Kaminsky

Argonne National Laboratory 9700 S. Cass Avenue

Argonne, IL 60439

V. A. Maroni

Argonne National Laboratory 9700 S. Cass Avenue

Argonne, IL 60439

P. M. Persiani

Argonne National Laboratory 9700 S. Cass Avenue

Argonne, IL 60439

M. Petrick

Engineering and Technology

Division

Argonne National Laboratory

$9700 \mathrm{~S}$. Cass Avenue

Argonne, IL 60439

W. E. Parkins, Manager

Atomics International

Component Engineering and

Technology Division

North American Rockwell

P. 0. Box 309

Canoga Park, CA 91304

D. Gurinsky

Brookhaven National Laboratory

ERDA Brookhaven Area Office

Upton, NY 11973

H. J. Kouts

Brookhaven National Laboratory

ERDA Brookhaven Area Office

Upton, NY 17973

S. Pearlstein

Brookhaven National Laboratory

ERDA Brookhaven Area Office

Upton, NY 11973

\section{OFFSITE}

J. R. Powell

Brookhaven National Laboratory ERDA Brookhaven Area Office Upton, NY 11973

A. J. Impink, Jr. Carnegie Melion University Pittsburgh, PA 15213

R. A. Gross

Plasma Research Laboratory

236 SW Mudd Bldg.

Columbia University

New York, NY 10027

W. C. Gough

Electric Power Research Inst.

3412 Hillview Ave.

Palo Alto, CA 94304

G. R. Hopkins

Gulf General Atomic

P.0. Box 1111

San Diego, CA 92112

Zeinab Sabri

Iowa State University

267 Sweeney Hall

Nuclear Engineering Department

Ames, IA 50010

R. Borg

Lawrence Livermore Laboratory

P.0. Box 808

Livermore, CA 94550

T. K. Fowler

Lawrence Livermore Laboratory

P.0. Box 808

Livermore, CA 94550

R. Moir

Lawrence Livermore Laboratory

P.0. Box 808

Livermore, CA 94550

A. Carl Haussmann

Lawrence Livermore Laboratory

P.0. Box 808

Livermore, CA 94550

J. Hovingh

Lawrence Livermore Laboratory

P. 0. Box 808

Livermore, CA 94550

R. F. Post

Lawrence Livermore Laboratory

P. 0. Box 808

Livermore, CA 94550

C. U. Taylor

Lawrence Livermore Laboratory

P.0. Box 808

Livermore, CA 94550 
$R$. Werner

Lawrence Livermore

Laboratory

P.0. Box 808

Livermore, CA 94550

L. L. Wood

Lawrence Livermore

Laboratory

P.0. Box 808

Livermore, CA 94550

W. Bauer

Division Supervisor

of Physical Research

Sandia Labs Livermore

Livermore, CA 94550

L. Booth

Los Alamos Scientific

Laboratory

CTN Research

P.0. Box 1663

Los Alamos, NM 87544

D. J. Dudziak

Los Alamos Scientific

Laboratory

CTN Research

P.0. Box 1663

Los Alamos, NM 87544

D. B. Henderson

Los Alamos Scientific Laboratory

CTN Research

P.0. Box 1663

Los Alamos, NM 87544

E. L. Kemp

Los Alamos Scientific

Laboratory

CTN Research

P.0. Box 1663

Los Alamos, NM 87544

F. L. Ribe

Los Alamos Scientific

Laboratory

CTN Research

P.0. Box 1663

Los Alamos, NM 87544

L. Stewart

Los Alamos Scientific Laboratory

CTN Research

P.0. Box 1663

Los Alamos, NM 87544

K. Thomassen

Los Alamos Scientific

Laboratory

CTN Research

P.0. Box 1663

Los Alamos, NM 87544
0 . K. Harling

Massachusetts Institute of

Technology

Cambridge, MA 02139

Bruno Coppi

Department of Physics

Massachusetts Institute of

Technology

Cambridge, MA 02139

L. Lidsky

Dept. of Nuclear Engineering

Massachusetts Institute of

Technology

Cambridge, MA 02139

Norm Rasmussen

Dept. of Nuclear Engineering

Massachusetts Institute of

Technology

Cambridge, MA 02139

David Rose

Massachusetts Institute of

Technology

Cambridge, MA 02139

R. E. Stickney

Mechanical Engineering

Massachusetts Institute of

Technology

Cambridge, MA 02139

J. J. Reinmann

NASA - Lewis Research Center

2100 Bookpark Rd.

Cleveland, $\mathrm{OH} \quad 44135$

Vincent Arp

National Bureau of Standards

Cryogenics Division

Boulder, CO 80302

J. F. Clarke

Oak Ridge National

Laboratory

P.0. Box Y

Oak Ridge, TN 37830

A. P. Fraas

Oak Ridge National

Laboratory

P. 0. Box Y

Oak Ridge, TN 37830

J. Rand McNally, Jr. Oak Ridge National

Laboratory

P. 0. Box Y

Oak Ridge, TN 37830

D. Steiner

Oak Ridge National

Laboratory

P. 0. Box Y

Oak Ridge, TN 37830
J. Scott

Oak Ridge National Laboratory

P. 0. Box X

Oak Ridge, TN 37830

J. Banford

Physics International

2700 Merced St.

San Leandro, CA 94577

R. A. Huse

Public Service Electric

and Gas Co.

80 Park Place

Newark, NJ 07101

M. Gottlieb

Princeton University, PPPL

P.0. Box 451

Princeton, NJ 08540

R. G. Mills

Princeton University

P.0. Box 451

Princeton, NJ 08540

E. C. Tanner

Princeton University

P.0. Box 451

Princeton, NJ 08540

H. Perkins

Dept. of Chemistry

Princeton University

Princeton, $\mathrm{NJ} 06540$

R. E. Gold

303 Sayre Hall

Forrestal Campus

P.0. Box 451

Princeton, $\mathrm{NJ} 06540$

M. Kristiansen

Texas Tech. University

Lubbock, TX 79409

A. F. Haught

United Aircraft Research Lab.

United Aircraft Corporation

East Hartford, CT 06108

L. Levine

U.S. Naval Research Laboratory

Washington, DC 20390

C. Z. Serpan, Jr.

U.S. Naval Research Laboratory

Washington, DC 20390

Francis Chen

University of California

Electronics Research

Laboratory

College of Engineering

Berkeley, CA 94720 
A. J. Lichtenberg University of California Electronics Research Laboratory

College of Engineering

Berkeley, CA 94720

Dave Okrent

U.C.L.A.

Los Angeles, CA 90024

C. D. Hendricks

University of Illinois

Nuclear Engineering

Laboratory

Urbana, IL 61801

G. H. Miley

University of Illinois

Nuclear Engineering

Laboratory

Urbana, IL 61801

Terry Kammash

University of Michigan

Nuclear Engineering

Department

Ann Arbor, MI 48105

Dean Abrahamson

University of Minnesota

School of Public

Affairs

Social Science

Building/309

Minneapolis, MN 55455

W. G. Davey

University of Texas

Department of Physics

Austin, TX 78712

E. Linn Draper, Jr. University of Texas

Department of Physics

Austin, TX 78712

W. E. Drummond University of Texas Department of Physics Austin, TX 78712

Abraham Hertzberg University of Washington Aerospace Research

Laboratory

316 Guggenheim

Seattle, WA 98105

A. L. Babb University of Washington Nuclear Eng ineering Department

Seattle, WA 98105
R. Conn

University of Wisconsin

Nuclear Engineering

Department

Madison, WI 53706

G. L. Kulcinski University of Wisconsin Nuclear Engineering

Department

Madison, WI 53706

C. W. Maynard University of Wisconsin

Nuclear Engineering

Department

Madison, WI 53706

D. Lichtman

Department of Physics

University of Wisconsin

Milwaukee, WE 53201

E. E. Donaldson

Washington State University

Deparment of Physics

Pullman, WA 99163

D. D. Mahlum

Division of Biomedical

and Environmental Research

Washington, DC 20545

J. V. Vanston

Engineering Science

Building

University of Texas

Austin, TX 78712

Leslie S. Ramsey

450 North 5th Street

Indiana, PA 15701 
ERDA Richland Operations 0ffice

W. A. Burns

Atlantic Richfield Hanford Company

J. D. Kaser

Hanford Engineering

Development Labs

D. G. Doran

H. H. Yoshikawa

Battelle-Northwest

D. T. Aase

G. S. Allison

T. W. Ambrose

D. G. Atteridge

D. A. Baker

J. L. Bates

M. A. Bayne

E. R. Bradley

J. L. Brimhall

R. L. Brodzinski

R. J. Brouns

L. R. Bunnell

L. L. Burger

S. H. Bush

N. E. Carter

T. D. Chikalla

R. G. Clark

T. L. Criswell

S. D. Dahlgren

M. T. Dana

D. E. Deonigi

R. L. Dillon

D. A. Dingee

P. J. Dionne

B. H. Duane

J. W. Finnigan

J. C. Fox

J. J. Fuquay

J. E. Garnier

R. D. Gastil

B. F. Gore

J. N. Hartley

A. J. Haverfield

U. P. Jenquin

A. B. Johnson, Jr.

R. H. Jones

T. J. Kabele

W. S. Kelly

H. E. Kissinger

D. A. Kottwitz

N. Laegried

B. R. Leonard, Jr

D. L. Lessor

H. B. Liemohn

R. C. Liikala

M. A. McKinnon

R. F. Maness

R. P. Marshall
Battelle-Northwest - Continued

E. S. Murphy

R. D. Melson

D. F. Newman

R. E. Nightingale

D. E. Olesen

L. T. Pedersen

R. T. Perry

D. R. Pratt

L. A. Rancitelli

J. F. Remark

U. S. Renné

10 R. E. Rhoads

W. O. Richmond

W. F. Sandusky

L. C. Schmid

N. M. Sherer

E. P. Simonen

R. I. Smith

J. K. Soldat

C. W. Stewart

K. B. Stewart

R. W. Stewart

J. A. Strand

D. L. Styris

A. M. Sutey

V. L. Teofilo

G. L. Tingey

M. T. Thomas

R. C. Thompson

L. H. Toburen

T. J. Trapp

R. Wang

R. E. Westerman

L. D. Williams

10 J. R. Young

M. G. Zimmerman

1 Technical Publications (BH)

5 Technical Information 